\title{
Expression of multidrug resistance-associated protein l, P-glycoprotein, and thymidylate synthase in gastric cancer patients treated with 5-fluorouracil and doxorubicin-based adjuvant chemotherapy after curative resection
}

\author{
J-H Choi', H-Y Lim*,', HJ Joo', HS Kim', JW Yi', HC Kim', YK Cho ${ }^{3}$, MW Kim ${ }^{3}$ and KB Lee \\ 'Department of Hematology-Oncology, Ajou University School of Medicine, Suwon, 442-72I, Korea (Rep.); ' Department of Pathology, Ajou University School of \\ Medicine, Suwon, 442-72I, Korea (Rep.); ${ }^{3}$ Department of Surgery, Ajou University School of Medicine, Suwon, 442-721, Korea (Rep.)
}

Both 5-fluorouracil and doxorubicin are commonly used agents in chemotherapy of gastric cancer in adjuvant setting as well as metastatic disease. In a variety of malignancies, high expression of multidrug resistance-associated protein I and P-glycoprotein has been associated with resistance to doxorubicin, whereas 5-fluorouracil resistance has correlated with the level of thymidylate synthase expression. We evaluated the expression of multidrug resistance-associated protein I, P-glycoprotein, and thymidylate synthase using immunohistochemistry in 103 locally advanced gastric cancer patients (stage IB-IV) who underwent 5-fluorouracil and doxorubicin-based adjuvant chemotherapy after curative resection and investigated the association between their expression and clinicopathologic characteristics including prognosis of the patients. While high expression ( $\geqslant 5 \%$ of tumour cells positive) of multidrug resistance-associated protein I and P-glycoprotein was observed in 70 patients (68\%) and 42 patients (41\%), respectively, 65 patients $(63 \%)$ had primary tumours with high expression ( $\geqslant 25 \%$ of tumour cells positive) of thymidylate synthase. There was a significant association between multidrug resistance-associated protein I and Pglycoprotein expression $(P<0.000 \mathrm{I})$ as well as P-glycoprotein and thymidylate synthase expression $(P<0.000 \mathrm{I})$. High multidrug resistance-associated protein I and P-glycoprotein expressions were associated with well and moderately differentiated histology $(P<0.0001$ and $P=0.03$, respectively) and intestinal type $(P<0.0001$ and $P=0.009$, respectively). High multidrug resistance-associated protein I expression correlated with lymph node metastasis $(P=0.037)$, advanced stage $(P=0.015)$, and older age $(P=0.02 \mathrm{I})$. Five-year disease-free survival and overall survival of total patients were $55.2 \%$ and $56.2 \%$, respectively, with a median follow-up of 68 months. There were no significant differences in disease-free survival and overall survival according to the expression of multidrug resistance-associated protein I $(P=0.902$ and $P=0.975$, respectively), $P$ glycoprotein ( $P=0.987$ and $P=0.955$, respectively), and thymidylate synthase $(P=0.604$ and $P=0.802$, respectively). Concurrent high expression of these proteins (high multidrug resistance-associated protein I/P-glycoprotein, high multidrug resistanceassociated protein I/thymidylate synthase, high P-glycoprotein/thymidylate synthase) did not correlate with disease-free survival or overall survival. Even high expression of all three proteins was not associated with poor disease-free survival $(P=0.9 \mid 9)$ and overall survival $(P=0.852)$. In conclusion, high expression of multidrug resistance-associated protein I, P-glycoprotein, and thymidylate synthase did not predict poor prognosis of gastric cancer patients treated with 5-fluorouracil and doxorubicinbased adjuvant chemotherapy. A larger study including patients treated with surgical resection alone would be necessary. British Journal of Cancer (2002) 86, 1578-1585. DOl: 10.1038/sj/bjc/6600305 www.bjcancer.com (c) 2002 Cancer Research UK

Keywords: gastric cancer; multidrug resistance-associated protein I; P-glycoprotein; thymidylate synthase; adjuvant chemotherapy; prognosis

Gastric cancer is the most common malignancy in many countries including Korea (Fuchs and Mayer, 1995; Suh et al, 2000). The prognosis of patients with locally advanced gastric cancer is generally poor even with curative resection, which is an essential treatment for the long-term survival of patients (Noguchi et al, 1989; Fuchs and Mayer, 1995). Adjuvant chemotherapy has failed to demonstrate a significant survival benefit for such patients in

*Correspondence: H-Y Lim; E-mail: hylim@madang.ajou.ac.kr Revised 3 January 2002; accepted 20 March 2002 most randomized trials and meta-analyses although a recent study showed improved survival with postoperative chemoradiotherapy compared to surgery alone (Krook et al, 1991; Hermans et al, 1993; Fuchs and Mayer, 1995; Lise et al, 1995; Macdonald et al, 1995; Kelsen, 1996; Kim et al, 1998; Cirera et al, 1999; Earle and Maroun, 1999; Macdonald et al, 2001).

In adjuvant chemotherapy of gastric cancer, 5-fluorouracil (5FU) and doxorubicin have been commonly used in combination (Krook et al, 1991; Hermans et al, 1993; Lise et al, 1995; Macdonald et al, 1995; Kelsen, 1996; Kim et al, 1998; Earle and Maroun, 1999). Since the intrinsic or acquired resistance of cancer 
cells to these agents is the most important cause of the failure of adjuvant chemotherapy, identification of molecules associated with the resistance of tumours to anticancer drugs can provide valuable information in adjuvant chemotherapy of gastric cancer.

In terms of resistance to 5-FU, thymidylate synthase (TS), which is a critical target of 5-FU, has been widely investigated. TS catalyses the methylation of deoxyuridine monophosphate to deoxythymidine monophosphate, which is an essential process for DNA synthesis (Pinedo and Peters, 1988). High expression of TS may be associated with 5-FU resistance in a variety of malignancies including gastric cancer (Johnston et al, 1992, 1995; Lenz et al, 1996). For doxorubicin, multidrug resistance (MDR), which means the resistance of cancer cells against several anticancer drugs, has been considered as one of the important causes of drug resistance (Goldstein et al, 1989; Gottesman and Pastan, 1993). The bestcharacterised mechanism of MDR is overexpression of P-glycoprotein (P-gp) encoded by MDR1 gene (Goldstein et al, 1989; Gottesman and Pastan, 1993). P-gp is 170-Kda transmembrane protein and functions as an adenosine triphosphate-dependent drug efflux pump (Goldstein et al, 1989; Gottesman and Pastan, 1993). It is responsible for resistance of cancer cells to a wide range of structurally unrelated cytotoxic agents including doxorubicin, etoposide, vinca alkaloid, and actinomycin-D (Goldstein et al, 1989; Gottesman and Pastan, 1993). In addition to P-gp, multidrug resistance-associated protein1 (MRP1), 190-Kda membrane bound glycoprotein encoded by MRP1 gene, has been found to be involved in the resistance of cancer cells to the same category of anticancer drugs as in P-gp with similar mechanism (Cole et al, 1992; Hipfner et al, 1999). Moreover, MRP1 expression has been associated with resistance to chemotherapeutic agents or poor survival in breast cancer, neuroblastoma, lung cancer, and gastric cancer (Endo et al, 1996a,b; Norris et al, 1996; Nooter et al, 1997; Young et al, 1999).

In gastric cancer patients who underwent surgical resection with or without adjuvant chemotherapy, several investigators have reported the prognostic significance of TS, MRP1, and P-gp with conflicting results (Endo et al, 1996a; Monden et al, 1997; Kuniyasu et al, 1998; Takebayashi et al; 1998; Suda et al, 1999; Choi et al, 2001). We have recently reported that expression of TS did not predict poor survival in 103 gastric cancer patients treated with 5-FU and doxorubicin-based adjuvant chemotherapy after curative resection (Choi et al, 2001). We evaluated the expression of MRP1, $\mathrm{P}$-gp, and TS using the same cohort with longer follow-up and investigated the association between their expression and various clinicopathologic characteristics including prognosis of the patients.

\section{MATERIALS AND METHODS}

\section{Patients}

Included in this study were 103 patients with locally advanced gastric adenocarcinoma who underwent 5-FU and doxorubicinbased adjuvant chemotherapy after curative surgical resection at Ajou University Medical Center in Suwon, Korea, between July 1994 and October 1996. All patients had a postsurgical pathologic stage ranging from IB to IV without evidence of distant metastasis according to the American Joint Committee on Cancer (1997) TNM classification. Patients with distant abdominal lymph node metastasis (M1) were excluded.

In terms of adjuvant chemotherapy, the most commonly administered regimen was FA (5-FU, doxorubicin) with OK-432 (51 patients), followed by FAM (5-FU, doxorubicin, mitomycin-C) (33 patients), FA (11 patients), and FA with lentinan (eight patients). Chemotherapy was usually started 2-3 weeks after surgery. In FA regimen with or without immunotherapy (OK432 or lentinan), 5 -FU ( $500 \mathrm{mg} \mathrm{m}^{-2}$ per day) was given by intravenous (i.v.) infusion for $30 \mathrm{~min}$ on days 1,8 and 15 , and doxorubicin $\left(40 \mathrm{mg} \mathrm{m}^{-2}\right)$ was given by rapid i.v. injection on day 1 . The treatment was repeated every 3 weeks for 12 cycles. OK-432 (2.0 Klinishe Einheit/day) and lentinan ( $2 \mathrm{mg} /$ day $)$ were administered intramuscularly and intravenously, respectively, weekly throughout the FA chemotherapy period. In FAM regimen, 5-FU (1000 $\mathrm{mg} \mathrm{m}^{-2}$ per day) was given by continuous i.v. infusion on days 1 to 3 , and doxorubicin $\left(40 \mathrm{mg} \mathrm{m}^{-2}\right)$ and mitomycin-C (10 $\mathrm{mg} \mathrm{m}^{-2}$, every other cycle) were administered by rapid i.v. injection on day 1 . The treatment was repeated every 4 weeks for 12 cycles and mitomycin- $\mathrm{C}$ was administered every 8 weeks. The other characteristics of patients including the definition of curative section and follow-up schedule after treatment were previously described (Choi et al, 2001).

\section{Immunohistochemical staining}

Immunohistochemical staining of formalin-fixed, paraffinembedded tumour tissue was performed using MRPr1 monoclonal antibody against MRP1 (Signet Laboratories, Dedham, MA, USA), JSB-1 monoclonal antibody against P-gp (Signet Laboratories, Dedham, MA, USA), and TS 106 monoclonal antibody against TS (Neomarkers, Fremont, CA, USA) as described previously (Choi et al, 2001).

Formalin-fixed, paraffin-embedded sections of colon adenocarcinoma known to have high expression of TS and normal colon tissue were used as positive controls for TS and P-gp, respectively. The negative controls for TS and P-gp were made by the omission of the primary antibody during the process of immunohistochemical staining. For MRP1, cytospin preparation of the MRP1overexpressing doxorubicin-resistant human lung cancer cell line GLC4/ADR and its drug-sensitive parental cell line GLC4, which were kindly provided by Dr EG de Vries (Groningen University, Groningen, The Netherlands), were used as positive and negative control, respectively.

\section{Tissue evaluation}

The slides were examined independently by two observers (H.J.J. and K.B.L) blinded to both clinical and pathologic data. The expression of TS was divided into high TS (greater than or equal to $25 \%$ of tumour cells positive) and low TS (less than $25 \%$ of tumour cells positive or no staining) groups as reported previously (Choi et al, 2001). The expression of MRP1 and P-gp was also classified into high (greater than or equal to $5 \%$ of tumour cells positive) and low (less than $5 \%$ of tumour cells positive or no staining) based on the extent of staining.

\section{Statistical analysis}

Disease-free survival (DFS) and overall survival (OS) were calculated using Kaplan-Meier Method (Kaplan and Meier, 1958). Disease-free survival was defined as the time from the day of operation to a documented recurrence, or second primary cancer, or death from any other cause. Data on patients who did not have a recurrence were censored at the last follow-up. Overall survival was defined as the time from the day of operation to death; data on survivors were censored at the last follow-up. The differences between the survival curves were tested by using the log-rank test. Comparison of variables according to the expression of drug-resistance proteins was evaluated with the Student's $t$-test and chisquare test.

\section{RESULTS}

\section{Patient characteristics}

Of 103 patients who were assessable to drug resistance proteins, 71 were male and 32 were female, and their median age was 53 years (range, 28 to 72 ). Stages were IB in 9 , II in 28 , IIIA in 31 , IIIB in 
17, and IV in 18 patients. The median number of chemotherapy cycles was 8 (range, 1 to 13 ).

\section{Association of expression of drug resistance proteins with patient and tumour characteristics}

TS staining pattern in gastric tumours and typical examples were previously reported (Choi et al, 2001). Within the study group, 65 patients $(63 \%)$ had primary tumours with high TS expression $(\geqslant 25 \%$ of tumor cells positive), and 38 patients $(37 \%)$ demonstrated low TS expression ( $<25 \%$ of tumour cells positive or no staining). The relationship between TS expression and patient and tumour characteristics was also previously reported (Choi et $a l, 2001)$. High TS expression was associated with poorly differentiated histology $(P=0.015)$ and mixed type tumours in Lauren's classification $(P=0.027)$.

Both MRP1 and P-gp staining pattern in gastric tumours showed predominantly cytoplasmic staining in tumour cells (Figure 1). High expression ( $\geqslant 5 \%$ of tumour cells positive) of MRP1 and P-gp in primary tumour was observed in 70 patients (68\%) and 42 patients (41\%), respectively. High MRP1 and Pgp expression were associated with well and moderately differentiated histology $(P<0.0001$ and $P=0.03$, respectively $)$ and intestinal type $(P<0.0001$ and $P=0.009$, respectively). High MRP1 expression correlated with lymph node metastasis $(P=0.037)$, advanced stage $(P=0.015)$, and older age $(P=0.021)$. There was no significant association between expression of MRP1 and P-gp and other patient and tumour characteristics (Table 1). MRP1 and P-gp expressions were significantly associated with each other $(P<0.0001)$ (Table 2). There was also significant association between $\mathrm{P}$-gp and TS expression
$(P<0.0001)$ (Table 2). Multidrug resistance-associated protein 1 and TS did not correlate with each other $(P=0.094)$.

\section{Association of expression of drug resistance proteins with outcome of patients}

The median follow-up duration of the survivors was 68 month (range: 53-80 months) and no patient was lost to follow-up. At the time of analysis, 40 patients had recurrences, and two had second primary cancer (hepatocellular carcinoma and laryngeal cancer, respectively). Forty-seven of the 103 patients have died. Death due to recurrence of gastric cancer occurred in 40 patients. Two patients died of gastrointestinal bleeding and pneumonia, respectively, without evidence of recurrence, one patient died of second primary cancer (hepatocellular carcinoma), and the causes of death were undetermined in four patients.

Five-year DFS and OS of total patients were $55.2 \%$ and $56.2 \%$, respectively. There were no significant differences in DFS and OS according to the expression of MRP1 $(P=0.902$ and $P=0.975$, respectively), $\mathrm{P}$-gp $(P=0.987$ and $P=0.955$, respectively), and TS $(P=0.604$ and $P=0.802$, respectively) (Figures $2-4)$. Concurrent high expression of these proteins (high MRP1 and P-gp, high MRP1 and TS, high P-gp and TS) did not correlate with DFS or OS (Table 3). Even high expression of all three proteins was not associated with poor DFS $(P=0.919)$ and OS $(P=0.852)$ (Table $3)$. The prognostic significance of other clinicopathologic characteristics was previously reported (Choi et al, 2001). There were no significant differences in DFS and OS according to other characteristics except size $(P=0.024$ and $P=0.017$, respectively) and location ( $P=0.019$ and $P=0.027$, respectively) of primary tumour with extended follow-up of patients.
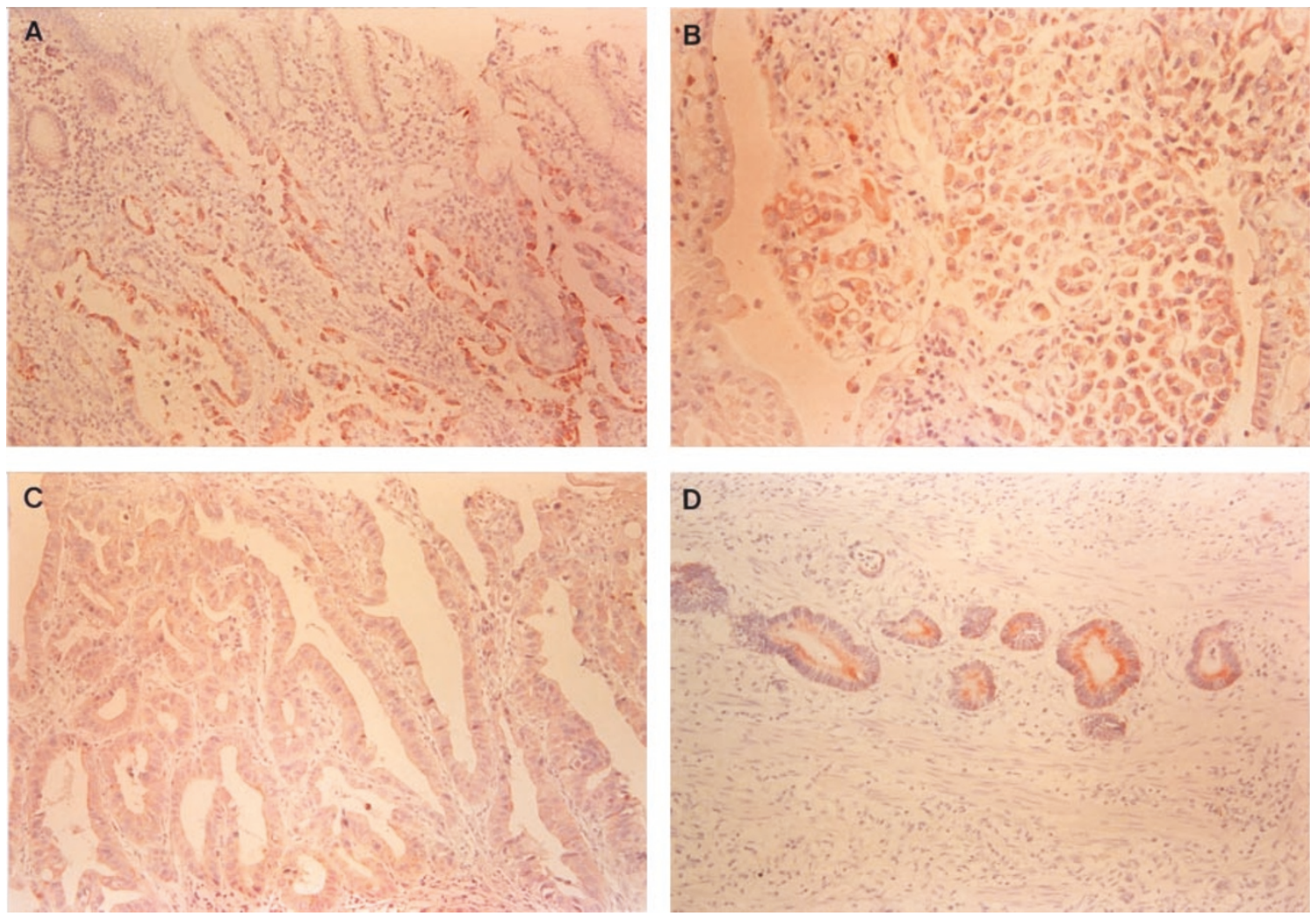

Figure I Immunohistochemical staining of MRPI and P-gP in gastric cancer. (A) Tubular adenocarcinoma showing strong immunoreactivity for MRPI compared to normal foveolar epithelium $(\times 100)$. (B) Signet ring cell carcinoma showing strong cytoplasmic staining of MRPI compared to non-neoplastic epithelium ( × 200). (C) Tubulopapillary adenocarcinoma showing diffuse immunoreactivity for P-gP ( × 200). (D) Strong expression of P-gp in cytoplasm of tubular adenocarcinoma $(\times 200)$ 
Table I Characteristics of patients according to MRPI and P-gp expression ${ }^{\mathrm{a}}$

\begin{tabular}{|c|c|c|c|c|c|c|}
\hline \multirow[b]{2}{*}{ Characteristics } & \multicolumn{2}{|c|}{ MRP I } & \multirow[b]{2}{*}{$P$ value } & \multicolumn{2}{|c|}{ P-gp } & \multirow[b]{2}{*}{$P$ value } \\
\hline & Low & High & & Low & High & \\
\hline Age & $49.1 \pm 10.4$ & $53.7 \pm 8.8$ & 0.021 & $50.8 \pm 9.1$ & $54.2 \pm 10.0$ & 0.072 \\
\hline $\begin{array}{l}\text { Gender } \\
\text { Male } \\
\text { Female }\end{array}$ & $\begin{array}{l}20(61) \\
13(39)\end{array}$ & $\begin{array}{l}51(73) \\
19(27)\end{array}$ & 0.210 & $\begin{array}{l}39(62) \\
23(38)\end{array}$ & $\begin{array}{r}33(79) \\
9(21)\end{array}$ & 0.079 \\
\hline $\begin{array}{l}\text { Type of operation } \\
\text { Subtotal } \\
\text { Total }\end{array}$ & $\begin{array}{l}18(55) \\
15(45)\end{array}$ & $\begin{array}{l}50(7 \mathrm{I}) \\
20(29)\end{array}$ & 0.091 & $\begin{array}{l}41(67) \\
20(33)\end{array}$ & $\begin{array}{l}27(64) \\
15(36)\end{array}$ & 0.758 \\
\hline Primary tumour size $(\mathrm{cm})$ & $5.4 \pm 3.4$ & $6.1 \pm 2.5$ & 0.245 & $5.9 \pm 3.1$ & $5.9 \pm 2.4$ & 0.921 \\
\hline $\begin{array}{l}\text { Tumour location } \\
\text { Lower } \\
\text { Mid } \\
\text { Upper } \\
\text { Diffuse }\end{array}$ & $\begin{array}{r}17(52) \\
8(24) \\
7(21) \\
1(3)\end{array}$ & $\begin{array}{r}38(54) \\
25(36) \\
5(7) \\
2(3)\end{array}$ & 0.190 & $\begin{array}{r}35(57) \\
14(23) \\
10(16) \\
2(3)\end{array}$ & $\begin{array}{r}20(48) \\
19(45) \\
2(5) \\
1(2)\end{array}$ & 0.064 \\
\hline $\begin{array}{l}\text { Borrmann type } \\
\text { I } \\
\text { II } \\
\text { III } \\
\text { IV }\end{array}$ & $\begin{array}{r}0(0) \\
9(27) \\
18(55) \\
6(18)\end{array}$ & $\begin{array}{r}6(9) \\
14(20) \\
45(64) \\
5(7)\end{array}$ & 0.099 & $\begin{array}{r}2(3) \\
18(30) \\
33(54) \\
8(13)\end{array}$ & $\begin{array}{r}4(10) \\
5(12) \\
30(71) \\
3(7)\end{array}$ & 0.067 \\
\hline $\begin{array}{l}\text { Tumour differentiation } \\
\text { Well } \\
\text { Moderate } \\
\text { Poor } \\
\text { Signet ring } \\
\text { Undifferentiated } \\
\text { Mucinous }\end{array}$ & $\begin{array}{r}0(0) \\
4(12) \\
16(49) \\
\mid 1(33) \\
0(0) \\
2(6)\end{array}$ & $\begin{array}{r}13(19) \\
27(39) \\
21(30) \\
6(9) \\
1(1) \\
2(3)\end{array}$ & $<0.0001$ & $\begin{array}{r}5(8) \\
13(2 \mid) \\
26(43) \\
12(20) \\
\mid(2) \\
4(7)\end{array}$ & $\begin{array}{r}8(19) \\
\mid 8(43) \\
\mid 1(26) \\
5(12) \\
0(0) \\
0(0)\end{array}$ & 0.030 \\
\hline $\begin{array}{l}\text { Lauren's classification } \\
\text { Intestinal } \\
\text { Diffuse } \\
\text { Mixed }\end{array}$ & $\begin{array}{r}9(27) \\
9(27) \\
15(46)\end{array}$ & $\begin{array}{r}48(69) \\
3(4) \\
19(27)\end{array}$ & $<0.0001$ & $\begin{array}{l}30(49) \\
12(20) \\
19(31)\end{array}$ & $\begin{array}{r}27(64) \\
0(0) \\
15(36)\end{array}$ & 0.009 \\
\hline $\begin{array}{l}\text { Lymphatic invasion } \\
\text { Yes } \\
\text { No }\end{array}$ & $\begin{array}{l}23(70) \\
10(30)\end{array}$ & $\begin{array}{l}55(79) \\
15(2 \mid)\end{array}$ & 0.327 & $\begin{array}{l}45(74) \\
16(26)\end{array}$ & $\begin{array}{r}33(79) \\
9(21)\end{array}$ & 0.577 \\
\hline $\begin{array}{l}\text { Depth of tumour invasion } \\
\text { T2 } \\
\text { T3 } \\
\text { T4 }\end{array}$ & $\begin{array}{r}12(36) \\
20(6 \mid) \\
1(3)\end{array}$ & $\begin{array}{r}30(43) \\
38(54) \\
2(3)\end{array}$ & 0.821 & $\begin{array}{r}27(44) \\
32(53) \\
2(3)\end{array}$ & $\begin{array}{r}15(36) \\
26(62) \\
\quad 1(2)\end{array}$ & 0.635 \\
\hline $\begin{array}{l}\text { Lymph node involvement } \\
\text { N0 } \\
\text { NI } \\
\text { N2 } \\
\text { N3 }\end{array}$ & $\begin{array}{r}4(12) \\
18(55) \\
10(30) \\
1(3)\end{array}$ & $\begin{array}{l}14(20) \\
23(33) \\
18(26) \\
15(21)\end{array}$ & 0.037 & $\begin{array}{r}8(13) \\
28(46) \\
19(31) \\
6(10)\end{array}$ & $\begin{array}{r}10(24) \\
13(31) \\
9(21) \\
10(24)\end{array}$ & $0.07 \mid$ \\
\hline $\begin{array}{l}\text { Stage } \\
\text { IB } \\
\text { II } \\
\text { IIIA } \\
\text { IIIB } \\
\text { IV }\end{array}$ & $\begin{array}{r}0(0) \\
13(39) \\
10(30) \\
8(24) \\
2(6)\end{array}$ & $\begin{array}{r}9(13) \\
15(21) \\
21(30) \\
9(13) \\
16(23)\end{array}$ & 0.015 & $\begin{array}{r}4(7) \\
16(26) \\
23(38) \\
10(16) \\
8(13)\end{array}$ & $\begin{array}{r}5(12) \\
12(29) \\
8(19) \\
7(17) \\
10(24)\end{array}$ & 0.251 \\
\hline $\begin{array}{l}\text { Chemotherapy } \\
\text { FA+OK- } 432^{b} \\
\text { FAM }^{\mathrm{b}} \\
\text { FA } \\
\text { FA+lentinan }\end{array}$ & $\begin{array}{r}18(55) \\
9(27) \\
4(12) \\
2(6)\end{array}$ & $\begin{array}{r}33(47) \\
24(34) \\
7(10) \\
6(9)\end{array}$ & 0.833 & $\begin{array}{r}31(51) \\
18(30) \\
8(13) \\
4(7)\end{array}$ & $\begin{array}{r}20(48) \\
15(36) \\
3(7) \\
4(10)\end{array}$ & 0.691 \\
\hline Cycles of chemotherapy & $8.4 \pm 3.3$ & $8.5 \pm 3.7$ & 0.813 & $8.2 \pm 3.5$ & $9.0 \pm 3.6$ & 0.248 \\
\hline
\end{tabular}

${ }^{a}$ Values are number or mean \pm standard deviation, with percentages in parentheses. ${ }^{b} \mathrm{~F}, 5-\mathrm{FU}$; $\mathrm{A}$, doxorubicin; M, mitomycin-C.

Table 2 Correlation of expression between MRPI and P-gp, TS and P-gP

\begin{tabular}{|c|c|c|c|c|c|c|}
\hline \multirow[b]{2}{*}{ Expression of P-gp } & \multicolumn{3}{|c|}{ Expression of MRP I } & \multicolumn{3}{|c|}{ Expression of TS } \\
\hline & Low & High & $P$ value & Low & High & $P$ value \\
\hline Low & 29 (88\%) & $32(46 \%)$ & $<0.0001$ & 32 (84\%) & $29(45 \%)$ & $<0.0001$ \\
\hline High & $4(12 \%)$ & 38 (54\%) & & $6(16 \%)$ & $36(55 \%)$ & \\
\hline
\end{tabular}



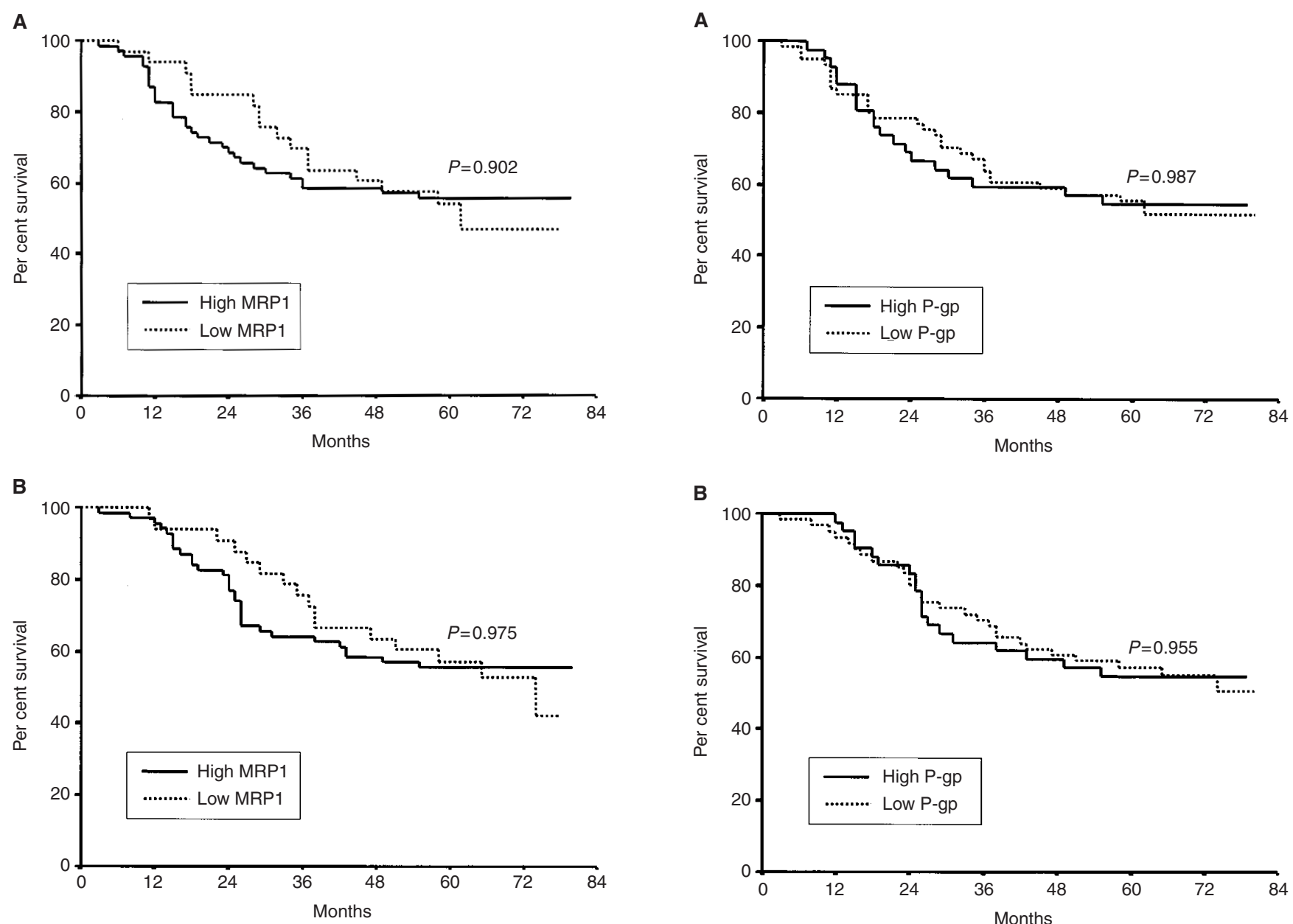

Figure 2 Disease-free survival $(\mathbf{A})$ and overall survival (B) of gastric cancer patients according to MRPI expression.

\section{DISCUSSION}

In this study, we evaluated the clinical significance of MRP1, P-gp, and TS known to be associated with resistance of tumours to 5-FU and doxorubicin in locally advanced gastric cancer patients treated with 5-FU and doxorubicin-based adjuvant chemotherapy after curative resection. The association between TS expression and clinicopathologic characteristics was previously reported (Choi et al, 2001).

In terms of MRP1 expression in primary tumours, $68 \%$ of tumours demonstrated high expression of MRP1. According to other studies, MRP1 expression was reported in $34-55 \%$ of patients with gastric cancer (Endo et al, 1996a,b; Takebayashi et al, 1998; Alexander et al, 1999). Multidrug resistance-associated protein 1 expression was associated with well and moderately differentiated histology and intestinal type, which was compatible with previous reports (Takebayashi et al, 1998; Alexander et al, 1999). Furthermore, a significant correlation was found between MRP1 expression and advanced stage. While there was no report showing such relationship in gastric cancer, a study demonstrated a significant association between high expression of MRP1 and advanced stage in breast cancer suggesting the role of MRP1 as a marker of aggressive tumour behaviour (Filipits et al, 1996). The mean age of patients with high MRP1 expression was higher than that of patients with low MRP1. This result has relevance to a higher proportion of intestinal type carcinoma, which occurs more often in old patients, in high MRP1 group compared to low MRP1

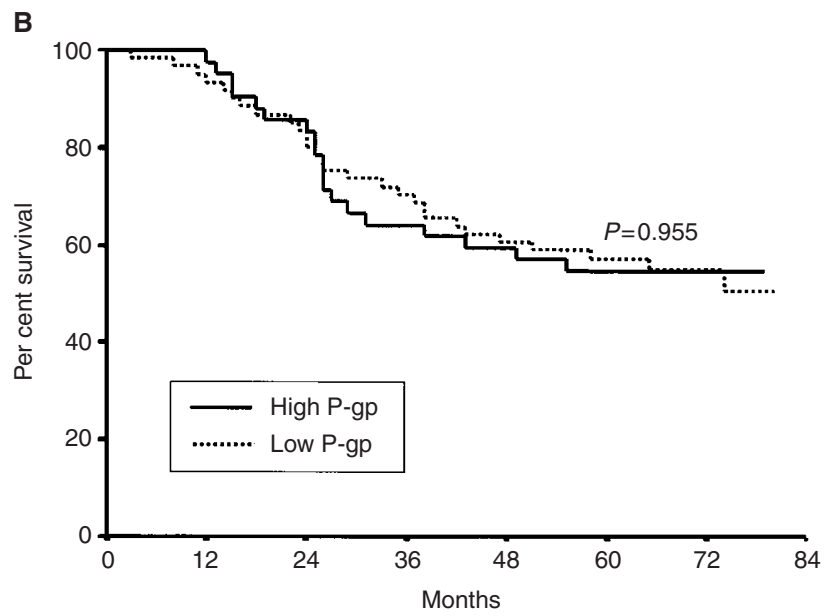

Figure 3 Disease-free survival $(\mathbf{A})$ and overall survival $(\mathbf{B})$ of gastric cancer patients according to P-gp expression.

group (Fuchs and Mayer, 1995). Furthermore, patients with intestinal type tumour showed a higher mean age compared to those with diffuse type in the present study (data not shown).

High expression of P-gp was observed in $41 \%$ and also associated with well and moderately differentiated histology and intestinal type as in MRP1. Similar proportion of high expression of P-gp and correlation with well differentiated tumour have been reported in other studies (Mizoguchi et al, 1990; Fujii et al, 1995; Monden et al, 1997; Motoo et al, 1998). One interesting finding was a strong association between MRP1 and P-gp expression. While two studies showed no significant correlation between MRP1 and P-gp in gastric cancer, conflicting results were reported in breast cancer (Filipits et al, 1996; Beck et al, 1998; Dexter et al, 1998; Alexander et al, 1999; Fan et al, 2000; Ferrero et al, 2000). The present study suggests that both MRP1 and P-gp are frequently expressed in well and moderately differentiated and intestinal type gastric cancer and closely associated with each other. There is a possibility that MRP1 and MDR1 gene may be coordinately regulated in gastric cancer tissue. There was also a significant correlation between P-gp and TS expression. It is an unexpected finding and further studies would be necessary to find a possible explanation for such a result.

In gastric cancer, the prognostic significance of TS, MRP1, and P-gp expression has been showing conflicting results (Endo et al, 1996a; Monden et al, 1997; Kuniyasu et al, 1998; Takebayashi et al; 1998; Suda et al, 1999; Choi et al, 2001). While TS expression predicted increased risk of recurrence and poor survival in 
patients treated with adjuvant chemotherapy after surgical resection in two studies, our previous study showed no significant differences in DFS and OS between high TS and low TS group (Kuniyasu et al, 1998; Suda et al, 1999; Choi et al, 2001). There are two studies that investigated the association between MRP1 expression and survival of patients treated with surgery, which failed to demonstrate the prognostic significance of MRP1 expression (Endo et al, 1996a; Takebayashi et al; 1998). On the other

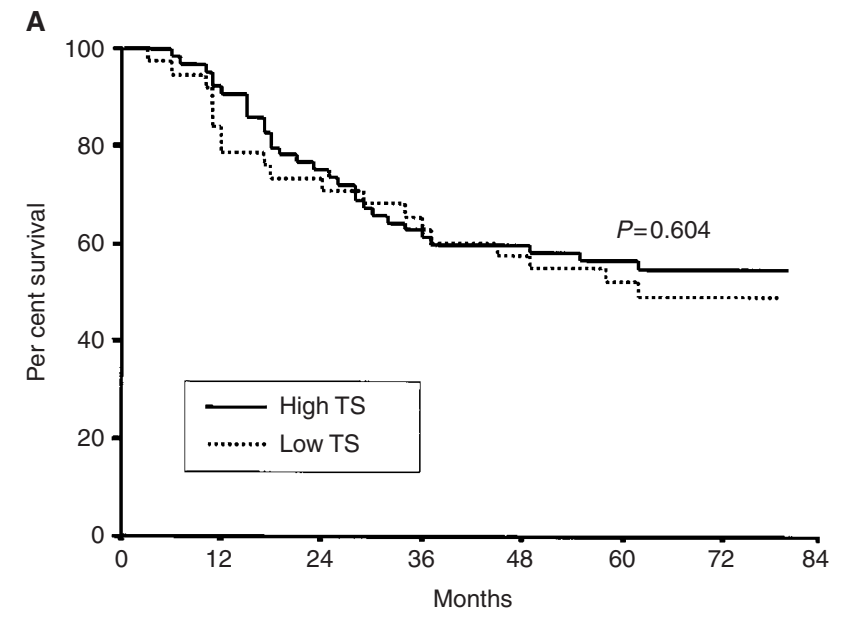

B

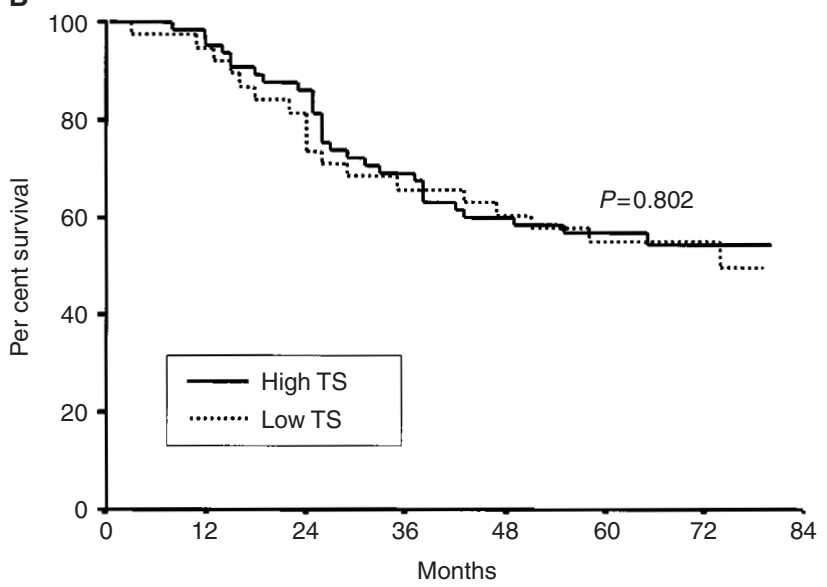

Figure 4 Disease-free survival (A) and overall survival (B) of gastric cancer patients according to TS expression. hand, a study suggested that high expression of P-gp was poor prognostic factor in gastric cancer patients who underwent surgical resection followed by adjuvant chemotherapy (Monden et al, 1997).

There were no significant differences in DFS and OS of gastric cancer patients according to the expression of MRP1, P-gp, and TS in the present study. We also investigated the prognostic significance of concurrent expression of these three drug resistance proteins. However, concurrent expression of drug resistance proteins did not predict increased recurrence or poor survival. Even high expression of all three proteins was not associated with poor prognosis. These results are a somewhat unexpected find considering the fact that we simultaneously investigated the clinical relevance of well-established drug resistance proteins, which are known to be involved in resistance of tumours to 5-FU and doxorubicin. The lack of prognostic implication of TS, MRP1, and P-gp expression in gastric cancer patients who underwent adjuvant chemotherapy could be explained as follows. The expression of these drug resistance proteins in primary tumours of gastric cancer patients may not reflect the drug resistance of microresidual or micrometastatic cancer cells which cause the recurrence (Choi et al, 2001). There is also a possibility that the gastric cancer patients with high expression of drug resistance proteins might experience greater survival benefit from adjuvant chemotherapy compared to patients with low expression as shown in other studies that investigated the expression of TS in rectal cancer and breast cancer (Johnston et al, 1994; Pestalozzi et al, 1997). However, a larger study including patients treated with surgical resection alone would be essential to clearly define the prognostic implication of these drug resistance proteins in adjuvant chemotherapy of gastric cancer.

To our knowledge, the present study is the first report that investigated the expression of TS, MRP1, and P-gp simultaneously in gastric cancer patients who underwent 5-FU and doxorubicinbased adjuvant chemotherapy. In other studies that investigated the clinical relevance of MRP1 or P-gp, the patients usually received fluoropyrimidine with or without mitomycin- $\mathrm{C}$, in which neither MRP1 nor P-gp is associated with drug resistance (Goldstein et al, 1989; Cole et al, 1992; Gottesman and Pastan, 1993; Endo et al, 1996a; Monden et al, 1997; Hipfner et al, 1999). Our results suggest the possibility that the expression of drug resistance-related proteins has little clinical significance in gastric cancer patients who received adjuvant chemotherapy. Similarly, a study that investigated the expression of MRP1 and MDR1 mRNA simultaneously in node-positive breast cancer patients who received anthracycline-based adjuvant chemotherapy, expression of MRP1 and MDR1 had no significant influence on survival (Ferrero et al, 2000).

Table 3 Disease-free and overall survival of the patients according to the concurrent expression of drug resistance proteins

\begin{tabular}{|c|c|c|c|c|c|}
\hline Characteristics & No. of Patients & 5-year disease-free survival (\%) & $P$ value & 5-year overall survival (\%) & $P$ value \\
\hline MRPI and P-gp & & & 0.756 & & 0.704 \\
\hline Both high & 38 & 52.5 & & 52.5 & \\
\hline Others & 65 & 56.8 & & 58.3 & \\
\hline MRPI and TS & & & 0.711 & & 0.840 \\
\hline Both high & 48 & 56.2 & & 56.2 & \\
\hline Others & 55 & 54.4 & & 56.2 & \\
\hline P-gp and TS & & & 0.818 & & 0.886 \\
\hline Both high & 36 & 55.4 & & 55.4 & \\
\hline Others & 67 & 55.1 & & 56.6 & \\
\hline MRPI and P-gp and TS & & & 0.919 & & 0.852 \\
\hline All high of wh & 32 & 52.9 & & 52.9 & \\
\hline Others & 71 & 56.2 & & 57.6 & \\
\hline
\end{tabular}


In conclusion, high expression of MRP1, P-gp, and TS including concurrent expression did not predict poor DFS and OS in patients with locally advanced gastric cancer treated with 5-FU and doxorubicin-based chemotherapy after curative resection. A larger study including patients treated with surgical resection alone would be necessary.

\section{REFERENCES}

Alexander D, Yamamoto T, Kato S, Kasai S (1999) Histopathological assessment of multidrug resistance in gastric cancer: expression of $\mathrm{P}$ glycoprotein, multidrug resistance-associated protein, and lung-resistance protein. Surg Today 29: 401-406

American Joint Committee on Cancer (1997) AJCC cancer staging manual, 5th edn, pp 71-76. Philadelphia: Lippincott-Raven

Beck J, Bohnet B, Brügger D, Bader P, Dietl J, Scheper RJ, Kandolf R, Liu C, Niethammer D, Gekeler V (1998) Multiple gene expression analysis reveals distinct differences between G2 and G3 stage breast cancers, and correlations of PKC $\eta$ with MDR1, MRP and LRP gene expression. Br J Cancer 77: $87-91$

Choi J-H, Lim H-Y, Nam DK, Kim HS, Cho DY, Yi JW, Kim HC, Cho YK, Kim MW, Joo HJ, Lee KB, Kim KB (2001) Expression of thymidylate synthase in gastric cancer patients treated with 5-fluorouracil and doxorubicin-based adjuvant chemotherapy after curative resection. Br J Cancer 84: $186-192$

Cirera L, Balil A, Batiste-Alentorn E, Tusquets I, Cardona T, Arcusa A, Jolis L, Saigi E, Guasch I, Badia A, Boleda M (1999) Randomized clinical trial of adjuvant mitomycin plus tegafur in patients with resected stage III gastric cancer. J Clin Oncol 17: 3810-3815

Cole SPC, Bhardwaj G, Gerlach JH, Mackie JE, Grant CE, Almquist KC, Stewart AJ, Kurz EU, Duncan AMV, Deeley RG (1992) Overexpression of a transporter gene in a multidrug-resitant human lung cancer cell line. Science 258: $1650-1654$

Dexter DW, Reddy RK, Geles KG, Bansal S, Myint MA, Rogakto A, Leighton JC, Goldstein LJ (1998) Quantitative reverse transcriptase-polymerase chain reaction measured expression of MDR1 and MRP in primary breast carcinoma. Clin Cancer Res 4: $1533-1542$

Earle CC, Maroun JA (1999) Adjuvant chemotherapy after curative resection for gastric cancer in non-Asian patients: revisiting a meta-analysis of randomised trials. Eur J Cancer 35: 1059-1064

Endo K, Maehara Y, Ichiyoshi Y, Kusumoto T, Sakaguchi Y, Ohno S, Sugimachi K (1996a) Multidrug resistance-associated protein expression in clinical gastric carcinoma. Cancer 77: $1681-1687$

Endo K, Maehara Y, Kusumoto T, Ichiyoshi Y, Kuwano M, Sugimachi K (1996b) Expression of multidrug-resistance-associated protein (MRP) and chemosensitivity in human gastric cancer. Int J Cancer 68: $372-377$

Fan K, Fan D, Cheng LF, Li C (2000) Expression of multidrug resistancerelated markers in gastric cancer. Anticancer Res 20: 4809-4814

Ferrero JM, Etienne MC, Formento JL, Francoual M, Rostagno P, Peyrottes I, Ettore F, Teissier E, Leblanc-Talent P, Namer M, Milano G (2000) Application of an original RT-PCR-ELISA multiplex assay for MDR1 and MRP, along with p53 determination in node-positive breast cancer patients. $\mathrm{Br}$ J Cancer 82: $171-177$

Filipits M, Suchomel RW, Dekan G, Haider K, Valdimarsson G, Depisch D, Pirker R (1996) MRP and MDR1 gene expression in primary breast carcinomas. Clin Cancer Res 2: $1231-1237$

Fuchs CS, Mayer RJ (1995) Gastric carcinoma. N Engl J Med 333: $32-41$

Fujii H, Tanigawa N, Muraoka R, Shimomatsuya T, Tanaka T (1995) Clinical significance of multidrug resistance and P-glycoprotein expression in patients with gastric carcinoma. J Surg Oncol 58: 63-69

Goldstein LJ, Galski H, Fojo A, Willingham M, Lai S-L, Gazdar A, Pirker R, Green A, Crist W, Brodeur GM, Lieber M, Cossman J, Gottesman MM Pastan I (1989) Expression of a multidrug resistance gene in human cancers. J Natl Cancer Inst 81: 116-124

Gottesman MM, Pastan I (1993) Biochemistry of multidrug resistance mediated by the multidrug transporter. Annu Rev Biochem 62: 385-427

Hermans J, Bonenkamp JJ, Boon MC, Bunt AMG, Ohyama S, Sasako M, Van de Velde CJH (1993) Adjuvant therapy after curative resection for gastric cancer: meta-analysis of randomized trials. J Clin Oncol 11: $1441-1447$

Hipfner DR, Deeley RG, Cole SPC (1999) Structural, mechanistic and clinical aspects of MRP1. Biochim Biophy Acta 1461: 359-376

\section{ACKNOWLEDGEMENTS}

The authors are grateful to Ms Geum Sook Jeong for secretarial assistance. The authors also express their appreciation to Dr EG de Vries at Groningen University, Groningen, The Netherlands for providing cell lines.

Johnston PG, Drake JC, Trepel J, Allegra CJ (1992) Immunological quantitation of thymidylate synthase using the monoclonal antibody TS 106 in 5fluorouracil-sensitive and -resistant human cancer cell lines. Cancer Res 52 . 4306-4012

Johnston PG, Fisher ER, Rockette HE, Fisher B, Wolmark N, Drake JC, Chabner BA, Allegra CJ (1994) The role of thymidylate synthase expression in prognosis and outcome of adjuvant chemotherapy in patients with rectal cancer. J Clin Oncol 12: 2640-2647

Johnston PG, Lenz H-J, Leichman CG, Danenberg KD, Allegra CJ, Danenberg PV, Leichman L (1995) Thymidylate synthase gene and protein expression correlate and are associated with response to 5-fluorouracil in human colorectal and gastric tumors. Cancer Res 55: 1407-1412

Kaplan EL, Meier P (1958) Non-parametric estimation from incomplete observations. J Am Statist Assoc 53: $457-481$

Kelsen DP (1996) Adjuvant and neoadjuvant therapy for gastric cancer. Semin Oncol 23: 379-389

Kim S-Y, Park HC, Yoon C, Yoon HJ, Choi YM, Cho KS (1998) OK-432 and 5-fluorouracil, doxorubicin, and mitomycin C (FAM-P) versus FAM chemotherapy in patients with curatively resected gastric carcinoma: a randomized phase III trial. Cancer 83: 2054-2059

Krook JE, O’Connell MJ, Wieand HS, Beart Jr RW, Leigh JE, Kugler JW, Foley JF, Pfeifle DM, Twito DI (1991) A prospective, randomized evaluation of intensive-course 5-fluorouracil plus doxorubicin as surgical adjuvant chemotherapy for resected gastric cancer. Cancer 67: 2454-2458

Kuniyasu T, Nakamura T, Tabuchi Y, Kuroda Y (1998) Immunohistochemical evaluation of thymidylate synthase in gastric carcinoma using a new polyclonal antibody: the clinical role of thymidylate synthase as a prognostic indicator and its therapeutic usefulness. Cancer 83: 1300-1306

Lenz H-J, Leichman CG, Danenberg KD, Danenberg PV, Groshen S, Cohen H, Laine L, Crookes P, Silberman H, Baranda J, Garcia Y, Li J, Leichman L (1996) Thymidylate synthase mRNA level in adenocarcinoma of the stomach: a predictor for primary tumor response and overall survival. $J$ Clin Oncol 14: 176-182

Lise M, Nitti D, Marchet A, Sahmoud T, Buyse M, Duez N, Fiorentino M, Santos JGD, Labianca R, Rougier P, Gignoux M (1995) Final results of a phase III clinical trial of adjuvant chemotherapy with the modified fluorouracil, doxorubicin, and mitomycin regimen in resectable gastric cancer. $J$ Clin Oncol 13: $2757-2763$

Macdonald JS, Fleming TR, Peterson RF, Berenberg JL, McClure S, Chapman RA, Eyre HJ, Solanki D, Cruz Jr AB, Gagliano R, Estes NC, Tangen CM, Rivkin S (1995) Adjuvant chemotherapy with 5-FU, adriamycin, and mitomycin-C (FAM) versus surgery alone for patients with locally advanced gastric adenocarcinoma: a Southwest Oncology Group Study. Ann Surg Oncol 2: $488-494$

Macdonald JS, Smalley SR, Benedetti J, Hundahl SA, Estes NC, Stemmermann GN, Haller DG, Ajani JA, Gunderson LL, Jessup JM, Martenson JA (2001) Chemoradiotherapy after surgery compared with surgery alone for adenocarcinoma of the stomach or gastroesophageal junction. $N$ Engl J Med 345: $725-730$

Mizoguchi T, Yamada K, Furukawa T, Hidaka K, Hisatsugu T, Shimazu H, Tsuruo T, Sumizawa T, Akiyama S-i (1990) Expression of the MDR1 gene in human gastric and colorectal carcinomas. J Natl Cancer Inst 82: 1679 1683

Monden N, Abe S, Sutoh I, Hishikawa Y, Kinugasa S, Nagasue N (1997) Prognostic significance of the expression of metallothionein, glutathioneS-transferase- $\pi$, and P-glycoprotein in curatively resected gastric cancer. Oncology 54: $391-399$

Motoo Y, Su S-B, Nakatani MT, Sawabu N (1998) Expression of multidrug rsistance gene $(m d r-1)$ mRNA in gastric and colorectal cancers. Anticancer Res 18: $1903-1906$

Noguchi Y, Imada T, Matsumoto A, Coit DG, Brennan MF (1989) Radical surgery for gastric cancer: a review of the Japanese experience. Cancer 64: $2053-2062$ 
Nooter K, de la Riviere GB, Look MP, van Wingerden KE, Henzen-Logmans SC, Scheper RJ, Flens MJ, Klijn JGM, Stoter G, Foekens JA (1997) The prognostic significance of expression of the multidrug resistance-associated protein (MRP) in primary breast cancer. $\mathrm{Br}$ J Cancer 76: 486-493

Norris MD, Bordow SB, Marshall GM, Haber PS, Cohn SL, Haber M (1996) Expression of the gene for multidrug-resistance-associated protein and outcome in patients with neuroblastoma. N Engl J Med 334: 231-238

Pestalozzi BC, Peterson HF, Gelber RD, Goldhirsch A, Gusterson BA, Trihia H, Lindtner J, Cortes-Funes H, Simmoncini E, Byrne MJ, Golouh R, Rudenstam CM, Castinglione-Gertsch M, Allegra CJ, Johnston PG (1997) Prognostic importance of thymidylate synthase expression in early breast cancer. J Clin Oncol 15: $1923-1931$

Pinedo HM, Peters GFJ (1988) Fluorouracil: biochemistry and pharmacology. J Clin Oncol 6: 1653-1664

Suda Y, Kuwashima Y, Tanaka Y, Uchida K, Akazawa S (1999) Immunohistochemical detection of thymidylate synthase in advanced gastric cancer: a prognostic indicator in patients undergoing gastrectomy followed by adjuvant chemotherapy with 5-fluoropyrimidines. Anticancer Res 19: 805-810
Suh CI, Suh K-A, Park S-H, Chang HJ, Ko J-W, Ahn D-H (2000) Annual report of the central cancer registry in Korea-1998. J Korean Cancer Assoc 32: $827-834$

Takebayashi Y, Akiyama S-i, Natsugoe S, Hokita S, Niwa K, Kitazono M, Sumizawa T, Tani A, Furukawa T, Aikou T (1998) The expression of multidrug resistance protein in human gastrointestinal tract carcinomas. Cancer 82: $661-666$

Young LC, Campling BG, Voskoglou-Nomikos T, Cole SPC, Deeley RG, Gerlach JH (1999) Expression of multidrug resistance protein-related genes in lung cancer: correlation with drug response. Clin Cancer Res 5: $673-680$ 